\title{
EFFECT OF CARBONATES AND BIVALENT CATIONS AND THEIR RELATIONSHIPS WITH SOIL ORGANIC MATTER FROM THE VIEW POINT OF AGGREGATE FORMATION
}

\author{
VLADIMÍR ŠIMANSKÝ ${ }^{1 *}$, MAREK KOLENČÍK ${ }^{1,2}$, LUBICA PUŠKELOVÁ ${ }^{3}$
}

${ }^{1}$ Slovak University of Agriculture, Nitra

${ }^{2}$ VŠB-Technical University of Ostrava, Ostrava-Poruba

${ }^{3}$ Slovak Academy of Sciences, Bratislava

ŠIMANSKÝ, V. - KOLENČÍK, M. - PUŠKELOVÁ, L'.: Effects of carbonates and bivalent cations and their relationships with soil organic matter from the view point of aggregate formation. Agriculture (Pol'nohospodárstvo), vol. 60, 2014, no. 3, pp. $77-86$.

The effect of carbonates on soil structure has not been sufficiently studied yet, despite the fact that in the literature their positive impact is mentioned mostly. Carbonates are the source of bivalent cations in soil solution and may be involved in stabilization of the aggregates, because negatively charged organic materials can be adsorbed onto the surface of clay by bivalent or polyvalent cations. We studied the effect of carbonates and bivalent cations and their relationships with soil organic matter (SOM) from the point of view of aggregate formation. The studies were carried out in several fields located on loamy Calcaric Chernozem, loamy Haplic and Mollic Fluvisols. The results showed that between exchangeable $\mathrm{Mg}^{2+}$ and water-stable macro-aggregates (WSA $\mathrm{ma}_{\mathrm{ma}}$ ) in size fractions $>2 \mathrm{~mm}$, positive correlations were found; however, the content of $\mathrm{Mg}^{2+}$ negative correlated with the contents of $\mathrm{WSA}_{\mathrm{ma}}$ in $<1 \mathrm{~mm}$ fractions as well as with water-stable micro-aggregates ( $\mathrm{WSA}_{\mathrm{mi}}$ ). The threshold limit for $\mathrm{Mg}^{2+}$ content for the formation of water-stable macro -aggregates was at $11.5 \mathrm{cmol} / \mathrm{kg}$ if all loamy soils were assessed together. A further increase resulted in a lower content of $\mathrm{WSA}_{\mathrm{ma}}$. If all investigated soils were assessed separately, these results did not enable us to distinguish the maximum formation of $\mathrm{WSA}_{\mathrm{ma}}$ by $\mathrm{Mg}^{2+}$ in individual soils. We observed a positive correlation between the sum of basic exchangeable cations (SBC) as well as between cation exchange capacity (CEC) and larger size fractions of $\mathrm{WSA}_{\mathrm{ma}}>2 \mathrm{~mm}$; however, between $\mathrm{SBC}$ as well as CEC and smaller size fractions of $\mathrm{WSA}_{\mathrm{ma}}<1 \mathrm{~mm}$ and $\mathrm{WSA}_{\mathrm{mi}}$ negative correlations were observed. Statistically significant negative correlations were observed between SOM content in WSA and carbonate content, and this effect was stronger in relation to the labile carbon. There were also positive correlations between SOM in WSA and SBC and CEC found if all loamy soils were assessed together.

Key words: soil structure, aggregation, soil organic carbon, Chernozem, Fluvisol

An understanding of causes for soil structure development has a practical importance because structure has a great influence on soil physical properties and plant growth, and it is an important feature in soil diagnostic horizons being base in soil classifi- cation as well. The process of soil aggregates formation (called aggregation) is the first step in the development of soil structure. Evidently, there must be some agents drawing the particles together to produce aggregates and also some means by which

doc. Ing. Vladimír Šimanský, PhD. (*Corresponding author), Department of Soil Science, FAFR - SUA Nitra, 94976 Nitra, Tr. A. Hlinku 2, Slovak Republic. E-mail: Vladimir.Simansky@uniag.sk

Mgr. Marek Kolenčík, PhD., Department of Soil Science, FAFR - SUA Nitra, 94976 Nitra, Tr. A. Hlinku 2, Slovak Republic, and Nanotechnology Centre, VŠB-Technical University of Ostrava, 17. listopadu 15, 70833 Ostrava-Poruba, Czech Republic. E-mail: marekkolencik@gmail.com

RNDr. L’ubica Puškelová, Geological Institute, Slovak Academy of Sciences, Dúbravská cesta 9, 84005 Bratislava, Slovak Republic. E-mail: lubica.puskelova@savba.sk 
they are bound rather firmly, so that the structural forms may persist. There are several theories concerning the aggregation process (Tisdall \& Oades 1982; Tisdall 1996; Amézketa 1999; Lal \& Shukla 2004; Six et al. 2004; Blanco-Canqui \& Lal 2007; Krol et al. 2013), which influences exogenous driving forces and the endogenous interactive forces. In the soil of Slovakia, the most important effect on aggregation has soil organic matter (SOM) (Šimanský 2012a; Šimanský \& Bajčan 2014) because SOM is one of the most important factors responsible for binding soil mineral particles together (Six et al. 2004; Bronick \& Lal 2005; Guggenberger et al. 2008; Šimanský \& Bajčan 2014), and this effect can be more intensive if soils contain free cations (Chan \& Heenan 1999). For example, positive effect of exchangeable $\mathrm{Ca}^{2+}$ and $\mathrm{Mg}^{2+}$ on aggregate stability in Haplic Luvisol was confirmed by the results of Šimanský (2012b). Negatively charged organic materials, such as polysaccharides, are adsorbed onto the surface of clay by $\mathrm{Ca}^{2+}$ or other polyvalent cations (Lal \& Shukla 2004). The effect of carbonates on soil structure has not yet been sufficiently studied, despite the fact that in literature (Le Bissonnais 1996; Amézketa 1999; Boix-Fayos et al. 2001) mostly their positive impact is mentioned. For example, Vaezi et al. (2008) studied the effect of $\mathrm{CaCO}_{3}$ on the stability of aggregates in the surface layers of soils in Italy and Iran. There was a positive correlation between calcium carbonate content and aggregates stability index. On the other hand, the results of Cerda (1996) and Lado et al. (2004) did not confirm this fact. Le Bissonnais (1996) stated that the effect of $\mathrm{CaCO}_{3}$ on the stability of aggregates is likely depending on its particle size distribution and clay content. This effect is more intensive, if soils contain enough clay and $\mathrm{CaCO}_{3}$ particle size is lesser than the size fraction of the silt. From this perspective, it would be interesting to know whether the effect of carbonates is sufficient for the formation of favourable soil structure in loamy soils. Under this context, we hypothesized that in soils such as Chernozems or Fluvisols (different soil types - based on the whole-profile soil morphology), which are the most fertile in Slovakia due to optimal chemical and physical properties (Bielek et al. 1998), the content of carbonates (source of bivalent cations) will be very important. In addition, several studies (Zhang \& Norton 2002; Lal \& Shukla 2004; Bronick \& Lal 2005) and as is mentioned above, the soil aggregates can be formed by SOM and mineral particles through cationic bridging. In general, carbonates are the source of $\mathrm{Ca}^{2+}$ and $\mathrm{Mg}^{2+}$, which can leach into the soil solution and may be involved in the stabilization of aggregates (Bronick \& Lal 2005).

Therefore, in this work the following were assessed: (1) the effect of carbonates and bivalent cations on the formation of individual size fractions of water-stable aggregates (WSA) and (2) testing the relationships between the content of SOM in WSA and the content of carbonates and bivalent cations if all investigated soils were assessed separately as well as together.

\section{MATERIAL AND METHODS}

Studied areas are located in the north-west part of Danube lowland (Figure 1). Geological substrates of the mentioned region are neogene clays, sands and gravels, in most such areas they are covered with loess and loess loam. Fluvial sediments are found along the Váh and Dudváh rivers. Soil samples were collected from the $0-0.2 \mathrm{~m}$ of A-horizons of Calcaric Chernozem, Haplic and Mollic Fluvisols (soil types classified according to the WRB 2006) at the fields in Bučany, Šulekovo and Trakovice, respectively. The sites have a temperate climate. The aver-

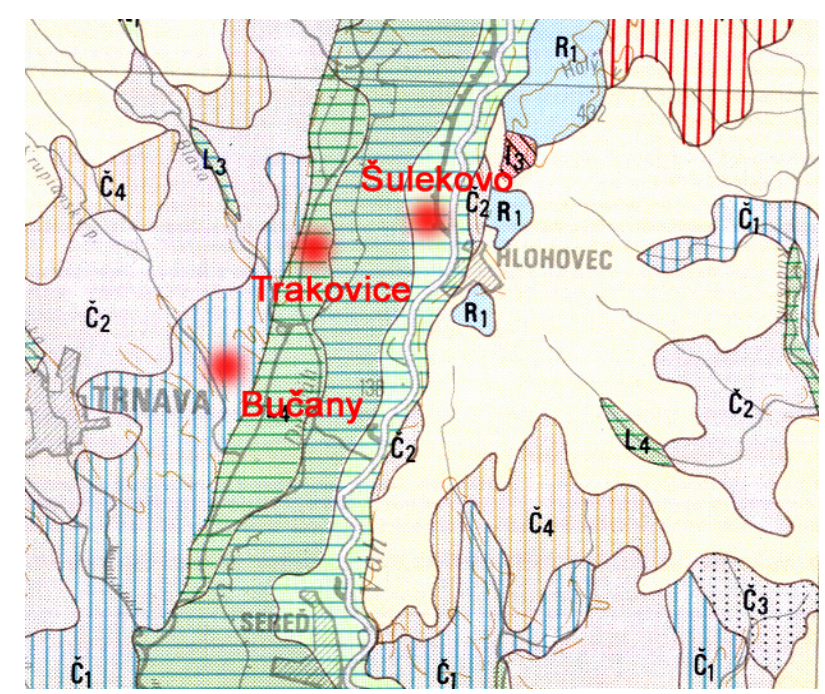

Figure 1. Selected sites in Slovakia 
age monthly precipitation and temperatures in 2011 were as follows: the average annual temperature is $10.1^{\circ} \mathrm{C}$ and average precipitation $501 \mathrm{~mm}$. The soils are deep, with weakly alkaline $\mathrm{pH}$. Soils are loamy, with average content of sand, silt and clay $-43 \%$, $42 \%$ and $15 \%$, respectively. Other soil characteristics in the top layer $(0-0.2 \mathrm{~m})$ are shown in Table 1.

All soils are used as arable land, with intensive cultivation of crops. In 2011, the sugar beet (Beta vulgaris L. var. altissima) was grown in all fields. The crop previous to sugar beet was spring barley (Hordeum sativum L.) in all cases. In autumn 2010, the soils were ploughed to the depth of $0.25 \mathrm{~m}$, and in case of Haplic Fluvisol the farmyard manure in dose of $40 \mathrm{t} / \mathrm{ha}$ was applied. Within the first decade of May, the sugar beet was sown in all fields.

Four different places were chosen on each field and the soil samples were always taken from these areas. Soil samples were taken from the depth of 0-0.2 $\mathrm{m}$ during the growing season of sugar beet in 2011 (May, 25; June, 18; July, 15; August, 14; September, 15 and October, 16). In laboratory, the large clods of soil were gently broken up along the natural fracture lines, and soil samples for the determination of individual size fractions of aggregates (undisturbed soil samples) were obtained. Part of the soil samples was grinded before analysis and we obtained soil samples for the determination of chemical characteristics. We determined soil $\mathrm{pH}-$ potentiometrically in the supernatant suspension of a 1:2.5 soil/distilled water (Fiala et al. 1999). Soil colloidal complex was characterized by the sum of basic exchangeable cations (SBC) and cation exchange capacity (CEC), which were determined. We also determined the contents of exchangeable cations such as $\mathrm{Ca}^{2+}$ and $\mathrm{Mg}^{2}$ by Kappen method (Fiala et al. 1999). Carbonates were determined by volumetric method using a Jankov calcimeter, based on the $\mathrm{CO}_{2}$ evolution after reacting with $\mathrm{HCl}$ (diluted with water in a 1:3 ratio). Soil organic carbon content $\left(\mathrm{C}_{\text {org }}\right)$ was measured using the wet combustion method (oxidation of SOM by a mixture of $0.07 \mathrm{~mol} / \mathrm{dm}^{3} \mathrm{H}_{2} \mathrm{SO}_{4}$ and $\mathrm{K}_{2} \mathrm{Cr}_{2} \mathrm{O}_{7}$ with titration using Mohr's salt), according to Tyurin (Dziadowiec \& Gonet 1999). In the grinded soil samples, particle-size distribution was determined by pipette method (Fiala et al. 1999). On the other hand, in undisturbed soil samples, individual size fractions of aggregates were determined by sieving $250 \mathrm{~g}$ of soil through sieves with diameter $>7,7-5,5-3.15$, $3.15-1,1-0.5,0.5-0.25$ and $<0.25 \mathrm{~mm}$ with amplitude 1.2 for $10 \mathrm{~min}$ in the AS 200 (dry sieving) device. These size fractions of air-dried aggregates were used for the determination of WSA distribution by Baksheev method (Vadjunina \& Korchagina 1986). Following size fractions of WSA $>5,5-3$, $3-2,2-1,1-0.5,0.5-0.25$ (macro-aggregates) and $<0.25 \mathrm{~mm}$ (micro-aggregates) were determined. In size fractions of WSA, the soil organic carbon content $\left(\mathrm{C}_{\text {org }}\right)$ was also determined (above-mentioned) according to Tyurin (Dziadowiec \& Gonet 1999), and labile carbon content $\left(\mathrm{C}_{\mathrm{L}}\right)$ was determined using $0.005 \mathrm{~mol} / \mathrm{dm}^{3} \mathrm{KMnO}_{4}$ (Loginow et al. 1987). Hence, soils that have difference between the $\mathrm{Ca}^{2+}$

T

Soil characteristics in the top layer $(0-0.2 \mathrm{~m})$

\begin{tabular}{|l|c|c|c|c|c|c|c|c|c|}
\hline \multirow{2}{*}{ Soil types } & $\mathrm{pH}$ & $\mathrm{CEC}$ & $\mathrm{Ca}^{2+}$ & $\mathrm{Mg}^{2+}$ & $\mathrm{CO}_{3}^{-}$ & $\mathrm{C}_{\mathrm{org}}$ & \multicolumn{2}{c|}{ sand } & \multicolumn{2}{c|}{ silt } & clay \\
\cline { 3 - 10 } & \multicolumn{3}{|c|}{$[\mathrm{cmol} / \mathrm{kg}]$} & {$[\%]$} & {$[\mathrm{g} / \mathrm{kg}]$} & \multicolumn{3}{|c|}{$[\%]$} \\
\hline $\begin{array}{l}\text { Calcaric } \\
\text { Chernozem }\end{array}$ & $7.8 \pm 0.04$ & $18.7 \pm 0.12$ & $9.3 \pm 1.5$ & $7.6 \pm 2.1$ & $9.28 \pm 1.04$ & $11.9 \pm 0.08$ & $43 \pm 3.95$ & $47 \pm 3.17$ & $10 \pm 1.48$ \\
\hline $\begin{array}{l}\text { Haplic } \\
\text { Fluvisol }\end{array}$ & $7.6 \pm 0.06$ & $17.8 \pm 0.16$ & $10.3 \pm 1.1$ & $10.5 \pm 2.1$ & $2.12 \pm 0.27$ & $21.2 \pm 0.11$ & $38 \pm 6.13$ & $40 \pm 2.85$ & $17 \pm 3.94$ \\
\hline $\begin{array}{l}\text { Mollic } \\
\text { Fluvisol }\end{array}$ & $7.8 \pm 0.03$ & $17.2 \pm 0.20$ & $8.6 \pm 1.4$ & $12.4 \pm 3.5$ & $11.6 \pm 0.94$ & $19.2 \pm 0.12$ & $47 \pm 3.69$ & $38 \pm 4.29$ & $14 \pm 1.83$ \\
\hline
\end{tabular}

$\mathrm{pH}-$ soil $\mathrm{pH}_{\mathrm{H} 2 \mathrm{O}}, \mathrm{CEC}-$ cation exchange capacity, $\mathrm{CO}_{3}^{-}-$content of carbonates, $\mathrm{C}_{\mathrm{org}}-$ soil organic carbon content 
and $\mathrm{Mg}^{2+}$ contents were carried out using X-ray diffraction analysis (XRD) for further examination of mineral composition. This method was directly oriented to the identification of primary and secondary crystalline phases (including clay minerals) from a typical soil aggregates (alluvial sediments) obtained from Trakovice and Šulekovo. Crystalline symmetry and structure parameters of solid phase were studied by X-ray powder diffraction (XRD) analysis, using the diffractometer PW1710 (Philips, The Netherlands) under the following conditions: Bragg-Brentano geometry (Theta-2Theta), $\mathrm{Cu}$ anticathode $\left(\lambda \alpha_{1}=1.54060 \AA\right)$, accelerating voltage 40 $\mathrm{kV}$, beam current $40 \mathrm{~m} \AA$. The step size was $0.01^{\circ} 2 \Theta$, the step time was $1 \mathrm{~s}$ per one step and the range of the measurement was $4-65^{\circ} 2 \Theta$.
The interrelations between SOM in WSA, chemical properties and individual size fractions of the WSA were determined through correlation matrix using the Statgraphics Centurion XV.I (Statpoint Technologies, Inc., USA). For the expression of dynamics of individual size fractions of WSA as well as for SOM in WSA, the quadratic polynomial regression models were used.

\section{RESULTS AND DISCUSSION}

As mentioned in Table 1, despite the fact that the soil had different genesis they had weakly alkaline $\mathrm{pH}$, good CEC and their texture was classified as loamy. In Haplic and Mollic Fluvisols, a higher

T a b $\quad$ b e 2

Dynamics of water-stable aggregates and soil organic matter content in water-stable aggregates

\begin{tabular}{|c|c|c|c|c|c|c|c|c|c|}
\hline \multicolumn{10}{|c|}{ Content of water-stable aggregates in \% } \\
\hline \multirow[t]{2}{*}{ Soil type } & \multirow{2}{*}{$\begin{array}{c}\text { Water-stable } \\
\text { aggregates }\end{array}$} & \multicolumn{6}{|c|}{ Date of sampling } & \multicolumn{2}{|c|}{$\begin{array}{c}\text { Polynomial } \\
\text { model }\end{array}$} \\
\hline & & May, 25 & June, 18 & July, 15 & August, 14 & September, 15 & October, 16 & $\mathrm{R}^{2}$ & $P$ \\
\hline \multirow{2}{*}{$\begin{array}{l}\text { Calcaric } \\
\text { Chernozem }\end{array}$} & $\mathrm{WSA}_{\mathrm{ma}}$ & 82 & 64 & 62 & 56 & 61 & 84 & \multirow{2}{*}{0.928} & \multirow{2}{*}{0.01} \\
\hline & $\mathrm{WSA}_{\mathrm{mi}}$ & 18 & 36 & 38 & 44 & 39 & 16 & & \\
\hline \multirow{2}{*}{$\begin{array}{l}\text { Haplic } \\
\text { Fluvisol }\end{array}$} & $\mathrm{WSA}_{\mathrm{ma}}$ & 73 & 88 & 86 & 92 & 88 & 94 & \multirow{2}{*}{0.768} & \multirow{2}{*}{0.05} \\
\hline & $\mathrm{WSA}_{\mathrm{mi}}$ & 27 & 12 & 14 & 8 & 12 & 6 & & \\
\hline \multirow{2}{*}{$\begin{array}{l}\text { Mollic } \\
\text { Fluvisol }\end{array}$} & $\mathrm{WSA}_{\mathrm{ma}}$ & 91 & 90 & 93 & 96 & 91 & 88 & \multirow{2}{*}{0.591} & \multirow{2}{*}{ n.s. } \\
\hline & $\mathrm{WSA}_{\mathrm{mi}}$ & 9 & 10 & 7 & 4 & 9 & 12 & & \\
\hline \multicolumn{10}{|c|}{$\mathrm{C}_{\text {org }}$ in WSA $[\mathrm{g} / \mathrm{kg}]$} \\
\hline \multirow{2}{*}{$\begin{array}{l}\text { Calcaric } \\
\text { Chernozem }\end{array}$} & $\mathrm{WSA}_{\mathrm{ma}}$ & 11.10 & 12.00 & 11.70 & 15.90 & 12.90 & 11.80 & 0.445 & n.s. \\
\hline & $\mathrm{WSA}_{\mathrm{mi}}$ & 9.20 & 8.90 & 9.10 & 9.80 & 9.60 & 9.20 & 0.294 & n.s. \\
\hline \multirow{2}{*}{$\begin{array}{l}\text { Haplic } \\
\text { Fluvisol }\end{array}$} & $\mathrm{WSA}_{\mathrm{ma}}$ & 21.80 & 21.40 & 21.10 & 21.90 & 20.40 & 20.80 & 0.442 & n.s. \\
\hline & $\mathrm{WSA}_{\mathrm{mi}}$ & 17.80 & 18.20 & 18.30 & 16.50 & 14.70 & 19.60 & 0.193 & n.s. \\
\hline \multirow{2}{*}{$\begin{array}{l}\text { Mollic } \\
\text { Fluvisol }\end{array}$} & $\mathrm{WSA}_{\mathrm{ma}}$ & 18.10 & 19.20 & 19.80 & 19.10 & 19.50 & 19.10 & 0.730 & 0.05 \\
\hline & $\mathrm{WSA}_{\mathrm{mi}}$ & 14.60 & 14.80 & 14.30 & 14.90 & 16.10 & 12.50 & 0.334 & n.s. \\
\hline \multicolumn{10}{|c|}{$\mathrm{C}_{\mathrm{L}}$ in WSA $[\mathrm{g} / \mathrm{kg}]$} \\
\hline \multirow{2}{*}{$\begin{array}{l}\text { Calcaric } \\
\text { Chernozem }\end{array}$} & $\mathrm{WSA}_{\text {ma }}$ & 0.06 & 0.06 & 0.08 & 0.13 & 0.12 & 0.14 & 0.875 & 0.01 \\
\hline & $\mathrm{WSA}_{\mathrm{mi}}$ & 0.07 & 0.05 & 0.05 & 0.06 & 0.07 & 0.09 & 0.955 & 0.001 \\
\hline \multirow{2}{*}{$\begin{array}{l}\text { Haplic } \\
\text { Fluvisol }\end{array}$} & $\mathrm{WSA}_{\mathrm{ma}}$ & 0.23 & 0.22 & 0.22 & 0.23 & 0.22 & 0.22 & 0.180 & n.s. \\
\hline & $\mathrm{WSA}_{\mathrm{mi}}$ & 0.13 & 0.14 & 0.13 & 0.12 & 0.12 & 0.17 & 0.530 & n.s. \\
\hline \multirow{2}{*}{$\begin{array}{l}\text { Mollic } \\
\text { Fluvisol }\end{array}$} & $\mathrm{WSA}_{\mathrm{ma}}$ & 0.12 & 0.15 & 0.16 & 0.13 & 0.13 & 0.14 & 0.217 & n.s. \\
\hline & $\mathrm{WSA}_{\mathrm{mi}}$ & 0.12 & 0.13 & 0.12 & 0.12 & 0.05 & 0.07 & 0.704 & 0.05 \\
\hline
\end{tabular}

$\mathrm{WSA}_{\mathrm{ma}}$ - content of water-stable macro-aggregates, $\mathrm{WSA}_{\mathrm{mi}}$ - content of water-stable micro-aggregates, $\mathrm{C}_{\text {org }}$ in WSA - soil organic carbon in water-stable aggregates, $\mathrm{C}_{\mathrm{L}}$ in WSA - labile carbon in water-stable aggregates n.s. - non-significant 
contents of exchangeable $\mathrm{Mg}^{2+}$ rather as $\mathrm{Ca}^{2+}$ were determined; however, opposite trend (more $\mathrm{Ca}^{2+}$ than $\mathrm{Mg}^{2+}$ ) was observed in Calcaric Chernozem. The $\mathrm{C}_{\text {org }}$ content was lowest in Calcaric Chernozem in comparison to other soil types. These differences are mainly not only due to different soil-forming processes (Duchaufour 1982) but also can be affected by soil management (Balashov \& Buchkina
2010; Slowinska-Jurkiewicz et al. 2013). For example, in studied Calcaric Chernozem, the content of $\mathrm{C}_{\text {org }}$ in A-horizon was influenced by inappropriate soil management practices (ploughing the soil on the slope and overall, which is a unsuitable choice of field for growing sugar beet). Due to intense soil (including carbonate loess) erosion on the slope down, sediment delivery was created there rather

$\mathrm{T}$ a

Correlation coefficients between chemical properties and size fractions content of water-stable aggregates and soil organic matter in size fractions of water-stable aggregates

\begin{tabular}{|c|c|c|c|c|c|}
\hline $\begin{array}{l}\text { Size fractions of water-stable } \\
\text { aggregates }\end{array}$ & $\mathrm{CaCO}_{3}$ & $\mathrm{Ca}^{2+}$ & $\mathrm{Mg}^{2+}$ & SBC & $\mathrm{CEC}$ \\
\hline$>5$ & n.s. & n.s. & $0.551^{+}$ & $0.668^{++}$ & $0.662^{++}$ \\
\hline $3-5$ & n.s. & n.s. & $0.538^{+}$ & $0.785^{+++}$ & $0.783^{+++}$ \\
\hline $2-3$ & n.s. & n.s. & $0.626^{++}$ & $0.788^{+++}$ & $0.787^{+++}$ \\
\hline $1-2$ & n.s. & n.s. & n.s. & n.s. & n.s. \\
\hline $0.5-1$ & n.s. & n.s. & $-0.512^{+}$ & $-0.591^{++}$ & $-0.584^{+}$ \\
\hline $0.25-0.5$ & n.s. & n.s. & n.s. & $-0.478^{+}$ & $-0.476^{+}$ \\
\hline$<0.25$ & n.s. & n.s. & $-0.475^{+}$ & $-0.684^{++}$ & $-0.685^{++}$ \\
\hline \multicolumn{6}{|c|}{$\begin{array}{l}\text { Soil organic carbon in size fractions } \\
\text { of water-stable aggregates }\end{array}$} \\
\hline$>5$ & $-0.490^{+}$ & n.s. & $0.475^{+}$ & $0.758^{+++}$ & $0.759^{+++}$ \\
\hline $3-5$ & n.s. & n.s. & $0.473^{+}$ & $0.844^{+++}$ & $0.844^{+++}$ \\
\hline $2-3$ & $-0.515^{+}$ & n.s. & $0.477^{+}$ & $0.799^{+++}$ & $0.800^{+++}$ \\
\hline $1-2$ & n.s. & n.s. & $0.469^{+}$ & $0.806^{+++}$ & $0.806^{+++}$ \\
\hline $0.5-1$ & n.s. & n.s. & n.s. & $0.838^{+++}$ & $0.838^{+++}$ \\
\hline $0.25-0.5$ & $-0.606^{++}$ & n.s. & n.s. & $0.773^{+++}$ & $0.774^{+++}$ \\
\hline$<0.25$ & $-0.574^{+}$ & n.s. & n.s. & $0.743^{+++}$ & $0.744^{+++}$ \\
\hline \multicolumn{6}{|c|}{$\begin{array}{l}\text { Labile carbon in size fractions of water- } \\
\text { stable aggregates }\end{array}$} \\
\hline$>5$ & $-0.658^{++}$ & n.s. & n.s. & $0.477^{+}$ & $0.484^{+}$ \\
\hline $3-5$ & $-0.864^{+++}$ & n.s. & n.s. & $0.499^{+}$ & $0.503^{+}$ \\
\hline $2-3$ & $-0.798^{+++}$ & n.s. & n.s. & $0.669^{++}$ & $0.673^{++}$ \\
\hline $1-2$ & $-0.636^{++}$ & n.s. & n.s. & $0.670^{++}$ & $0.672^{++}$ \\
\hline $0.5-1$ & $-0.741^{+++}$ & $0.472^{+}$ & n.s. & $0.651^{++}$ & $0.653^{++}$ \\
\hline $0.25-0.5$ & $-0.755^{+++}$ & n.s. & n.s. & $0.604^{++}$ & $0.611^{++}$ \\
\hline$<0.25$ & n.s. & n.s. & n.s. & $0.560^{+}$ & $0.562^{+}$ \\
\hline
\end{tabular}

$\mathrm{SBC}-$ sum of basic cations, CEC - cation exchange capacity

n.s. - non-significant; ${ }^{+} P \leq 0.05 ;{ }^{++} P \leq 0.01 ;{ }^{+++} P \leq 0.001$ 
thick depositional physical soil crust. The crust, consisting mostly of carbonate loess, covered and buried good A-horizon of Chernozem.

Changes in water-stable macro ( $\mathrm{WSA}_{\mathrm{ma}}$ ) and micro-aggregates $\left(\mathrm{WSA}_{\mathrm{mi}}\right.$ ) contents in different soil types during the vegetation season of sugar beet are given in Table 2. The content of $\mathrm{WSA}_{\mathrm{ma}}$ decreased mostly from May through August in the Calcaric Chermozem by $68 \%$, whereas during the same period an increase in $\mathrm{WSA}_{\mathrm{mi}}$ was observed. These trends had a statistically significant polynomial character. In Haplic Fluvisol, the highest content of $\mathrm{WSA}_{\text {ma }}$ $(94 \%)$ and the lowest content of $\mathrm{WSA}_{\mathrm{mi}}(6 \%)$ were determined in the end of the period (on October). In Mollic Fluvisol, the changes in WSA contents were minimal (without statistical significance) during the vegetation season of sugar beet.

The differences in the contents of $\mathrm{C}_{\text {org }}$ in WSA depended on the soil type (Table 2); however, they were almost identical during growing season of sugar beet in individual soil types. In Calcaric Chernozem, in WS$\mathrm{A}_{\text {ma }}$ and in $\mathrm{WSA}_{\text {mi }}, \mathrm{C}_{\text {org }}$ contents ranged from 11.1 to $15.9 \mathrm{~g} / \mathrm{kg}$ and from 9.1 to $9.8 \mathrm{~g} / \mathrm{kg}$, respectively. Almost double values of $\mathrm{C}_{\text {org }}$ in WSA were determined in Haplic and Mollic Fluvisols. A major part of the $\mathrm{C}_{\text {org }}$ is formed of the stable fraction of organic matter, and it has been turnedover thousands of times over the years (Hungate et al. 1996; Haynes 2005), but on the other hand, the labile fractions have a much shorter turnover time (Janzen et al. 1997) as it confirmed our results of $C_{L}$ in WSA (Table 2); therefore, the dynamics of labile carbon in WSA can be, due to its relatively wide range, considered as an important and sensitive indicator of the quality of soil environment under different soil management practices (Šimanský 2013).

Aggregation is further enhanced by biological and chemical processes such as flocculation and cementation by organo-mineral bonding (Dexter et al. 1988) while the aggregation process can be more intensive due to higher carbonates or bivalent cations content in the soil (Bronick \& Lal 2005). Therefore, one of the most important objectives in this study was to test the effect of carbonates and bivalent cations on the formation of individual size fractions of WSA in two ways: (1) if all investigated (classified as loamy) soils were assessed separately as well as and (2) together.

In Calcaric Chernozem, between carbonates, $\mathrm{Ca}^{2+}, \mathrm{Mg}^{2+}, \mathrm{SBC}, \mathrm{CEC}$ and individual size fractions of WSA no correlation was recorded. The content of $\mathrm{CO}_{3}^{-}$negatively $(-0.819, P \leq 0.05, \mathrm{n}=6)$ and positively $(-0.882, P \leq 0.05, \mathrm{n}=6)$ correlated with WSA $_{\mathrm{ma}} 3-5 \mathrm{~mm}$ in Haplic and Mollic Fluvisols, respectively. At the same time, we determined negative correlation $(-0.919, P \leq 0.01, \mathrm{n}=6)$ between $\mathrm{CO}_{3}^{-}$and $\mathrm{WSA}_{\text {ma }} 2-3 \mathrm{~mm}$ in Haplic Fluvisol. Between carbonates, bivalent cations and individual size fractions of WSA, no significant correlations were observed if all loamy soils were assessed separately. The content of carbonates, as well as exchangeable $\mathrm{Ca}^{2+}$, did not correlate with the content of individual size fractions of WSA; but on the other hand, significant correlations between exchangeable $\mathrm{Mg}^{2+}$ and WSA (Table 3) were surprising if all loamy soils were assessed together. In contrast to our results, Zhang and Norton (2002) reported that $\mathrm{Ca}^{2+}$ is more effective than $\mathrm{Mg}^{2+}$ in improving soil structure, because $\mathrm{Mg}^{2+}$ may have deleterious effect on aggregate stability by increasing clay dispersion. The extent of negative effect of $\mathrm{Mg}^{2+}$ compared with $\mathrm{Ca}^{2+}$ may depend on clay type (Amézketa 1999) and electrolyte concentration in the soil (Tisdall 1996). The higher content of $\mathrm{Mg}^{2+}$ in comparison to $\mathrm{Ca}^{2+}$ (in our cases in Haplic and Mollic Fluvisols), we can observe the unfavourable technological properties of the soil such as soil hardness (Zaujec et al. 2009). This was also confirmed by the mineralogical composition of aggregates at Šulekovo (Haplic Fluvisol)

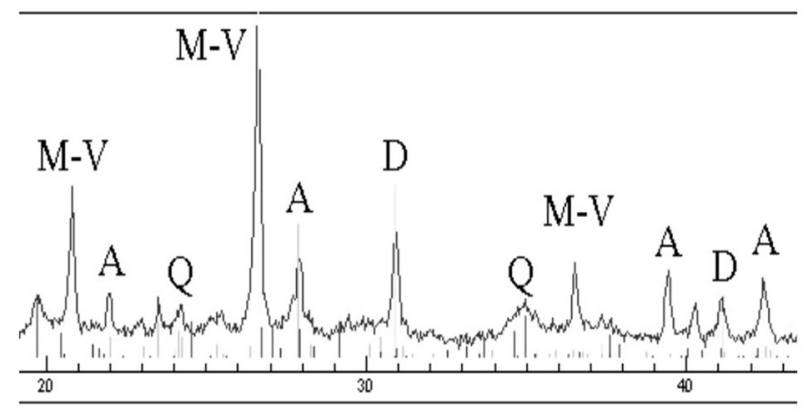

$\mathrm{M}-\mathrm{V}$-muscovite-vermiculite, $\mathrm{A}$-albite, $\mathrm{D}$-dolomite, Q - quartz which represented typical soil samples (alluvial sediment from Váh River) comes from Trakovice and Šulekovo (Slovakia)

Figure 2. X-ray - diffraction (XRD) patterns of minerals from soil aggregates 
and at Trakovice (Mollic Fluvisol). Mineralogical composition of soil aggregates was determined for XRD analysis (Figure 2). Dolomite $\mathrm{CaMg}\left(\mathrm{CO}_{3}\right)_{2}$ and quartz $\mathrm{SiO}_{2}$ were identified as the most dominant minerals in soil samples. However, significant content of albite and muscovite-vermiculite type of structure was confirmed. Generally, with the exception of clay minerals, various concentrations of $\mathrm{Ca}^{2+}$ and $\mathrm{Mg}^{2+}$ also still exist in carbonates. Our results indicate widely isomorphic substituting ability of $\mathrm{Mg}^{2+}$ versus $\mathrm{Ca}^{2+}$ with predominant dolomite phase compared with calcite content. Typical mineralogical association (dolomite, quartz, feldspar-albite and muscovite-vermiculite structure) was obtained from Haplic Fluvisol and Mollic Fluvisol at Trakovice and at Šulekovo, respectively. According to González et al. (2007), comparison of our mineralogical composition was almost similar in all cases; the differences were found with more calcite than dolomite. González et al. (2007) examined the Calcaric Fluvisols collected from abundant river terraces with intensive agricultural production. Pedogeochemical genesis and stability of detecting minerals in soil system were influenced on the transporting mechanisms and polygenetic alteration of rocks (Pozzuoli et al. 1992; Righi et al. 1993). Formation of characteristic Calcaric Chernozem from Central European region poses relative monotone mineralogical composition. Many studies elaborated the concentration of primary and secondary carbonate minerals from this type of soils as well as containing quartz and clay minerals with higher $\mathrm{Ca}^{2+}$ values (for instance, polysilicate montmorillonite) (Eckmier et al. 2007). A similar result was achieved by the considerably higher values of $\mathrm{Ca}^{2+}$ in soil aggregates from the Bučany district.

The relationship between $\mathrm{Mg}^{2+}$ and the content of $\mathrm{WSA}_{\mathrm{ma}}$ had significant polynomial character, this means that maximal formation of $\mathrm{WSA}_{\mathrm{ma}}$ was at the level of $\mathrm{Mg}^{2+}$ equal to $11.5 \mathrm{cmol} / \mathrm{kg}$ and the next increasing content of $\mathrm{Mg}^{2+}$ resulted in lower content of WSA $_{\text {ma }}$ (Figure 3a) if all loamy soils were assessed together. If all investigated soils were assessed separately, these results did not enable us to distinguish the maximum formation of $\mathrm{WSA}_{\text {ma }}$ by $\mathrm{Mg}^{2+}$ in individual soils. Therefore, we did not give any threshold limit for $\mathrm{Mg}^{2+}$ for Calcaric Chernozem, Haplic and Mollic Fluvisols separately.

As reported by Dimoyiannis et al. (1998) and Greene et al. (2002), the CEC is related to stable aggregates. We observed a positive correlation between SBC as well as CEC and higher size fractions of $\mathrm{WSA}_{\mathrm{ma}}>2 \mathrm{~mm}$; however, between $\mathrm{SBC}$ as well as CEC and smaller size fractions of $\mathrm{WSA}_{\mathrm{ma}}<1 \mathrm{~mm}$

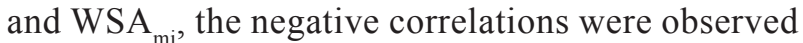
if all loamy soils were assessed together (Table 3). It means that if the content of bivalent cations in the soil is high, the soil structure is better. If all loamy soils were assessed separately, no significant correlation between SBC, CEC and individual size frac-
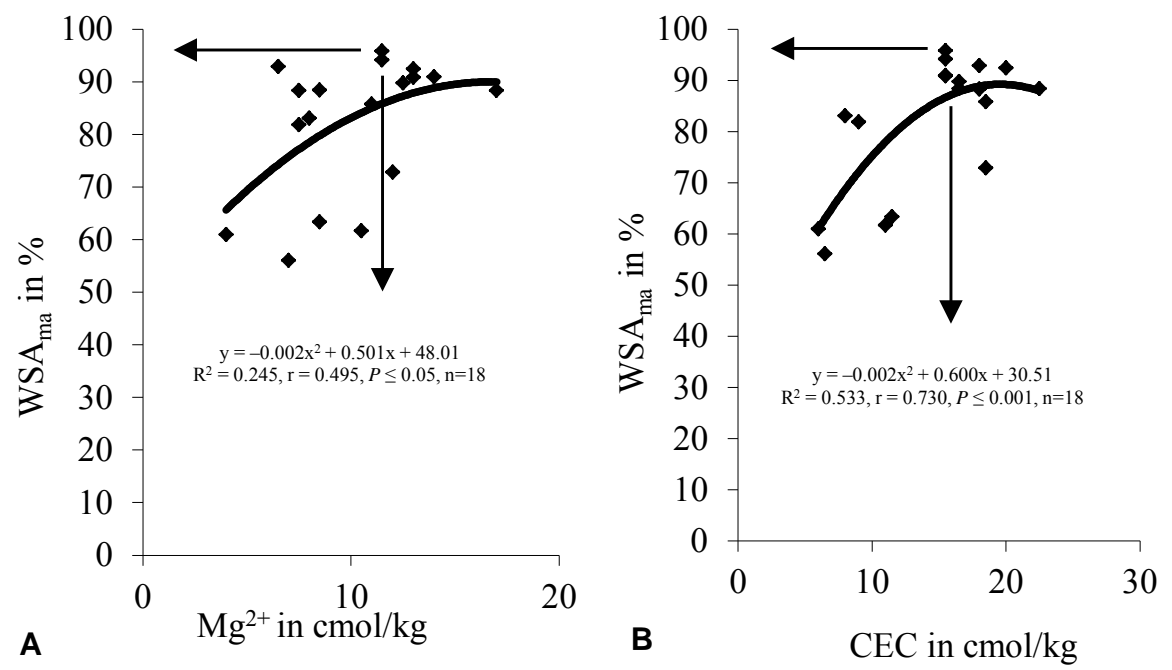

Figure 3. Relationship between A) exchangeable magnesium $\left(\mathrm{Mg}^{2+}\right)$ and water-stable macro-aggregates (WSA $\left.{ }_{\mathrm{ma}}\right)$ B) cation exchange capacity (CEC) and water-stable macro-aggregates 
tions of WSA was recorded. The maximal formation of $\mathrm{WSA}_{\mathrm{ma}}$ was at the level of CEC equal to 15.5 $\mathrm{cmol} / \mathrm{kg}$, and the next increasing content of CEC resulted in lower content of $\mathrm{WSA}_{\mathrm{ma}}$ (Figure $3 \mathrm{~b}$ ). If all investigated soils were assessed separately, a significant polynomial relationship between $\mathrm{CEC}$ and WSA $_{\text {ma }}$ was determined in Calcaric Chernozem. In this case, the maximal formation of $\mathrm{WSA}_{\mathrm{ma}}$ was at the level of CEC equal to $8.0 \mathrm{cmol} / \mathrm{kg}$. In Haplic and Mollic Fluvisols (assessed separately), we did not detect any significant polynomial relationships.

Aggregation process is connected with the interactions of mineral particles, cations and SOM (Bronick \& Lal 2005; Alagöz \& Yilmaz 2009; Šimanský 2011) and, therefore, the second objective was to test the relationships between the content of $\mathrm{C}_{\text {org }}$ and $\mathrm{C}_{\mathrm{L}}$ in individual size fractions of WSA and the content of carbonates and bivalent cations in loamy soils. Correlation coefficients are shown in Table 3, if all loamy soils were assessed together. Statistically significant negative correlations were observed between SOM in WSA and carbonate content, and this effect was stronger in relation to labile carbon. $\mathrm{C}_{\mathrm{L}}$ in water-stable micro-aggregates did not correlate with $\mathrm{CO}_{3}{ }^{-}$. Carbonates decreased the stability of micro-aggregates (Boix-Fayos et al. 2001). High carbonate concentration in the silt fraction decreases aggregation, suggesting that particle size may also influence the role of carbonates in aggregation (Dimoyiannis et al. 1998). In general, alkaline $\mathrm{pH}$ supports the accumulation of carbonates and, as presented by Haynes and Naidu (1998), large aggregates are formed in the soils of high $\mathrm{pH}$. In our case, the average $\mathrm{pH}$ of investigated loamy soils was $7.73 \pm 0.11$, but if soil moisture is increasing at high $\mathrm{C}_{\text {org }}$ content in the soil, the microbial respiration increases and carbonates are dissolved, and then we can observe the effect of bivalent cations (Boix-Fayos et al. 2001). Statistically significant positive correlations were observed between $\mathrm{C}_{\text {org }}$ in $\mathrm{WSA}_{\mathrm{ma}}>1 \mathrm{~mm}$ and $\mathrm{Mg}^{2+}$, but on the other hand, in case of $\mathrm{C}_{\mathrm{L}}$ in WSA, this effect was not observed. Positive correlations between SOM in WSA and $\mathrm{SBC}$ and CEC were found if all loamy soils were assessed together (Table 3). If all loamy soils were assessed separately, we detected negative significant correlation between $\mathrm{C}_{\text {org }}$ in $\mathrm{WSA}_{\mathrm{mi}}$ and $\mathrm{SBC}, \mathrm{CEC}$ in Calcaric Chernozem ( $\mathrm{r}=-0.900$ and $\mathrm{r}=-0.907$,
$P \leq 0.05, \mathrm{n}=6)$ as well as in Mollic Fluvisol ( $\mathrm{r}=-0.906$ and $\mathrm{r}=-0.903, P \leq 0.05, \mathrm{n}=6$ ). On the other hand, in Haplic Fluvisol, we detected positive significant correlation between $\mathrm{C}_{\text {org }}$ in $\mathrm{WSA}_{\mathrm{ma}}>5$ $\mathrm{mm}$ and size fraction 3-5 $\mathrm{mm}$ and SBC, CEC. Significant correlation between $\mathrm{C}_{\mathrm{L}}$ in WSA, SBC and CEC were detected if all soils were assessed separately.

\section{CONCLUSION}

Even though the soils are different from pedogenesis view point, they had the same particle-size distribution and so we tried to generalize our results on the basis of this factor. Our results show the fact that more intensive aggregation process in loamy soils is connected with high content of basic exchangeable cations, and high value of CEC and stabile organic matter content in WSA. The higher content of exchangeable $\mathrm{Mg}^{2+}$ rather than $\mathrm{Ca}^{2+}$ was significantly related to the formation of larger size fractions of water-stable macro-aggregates $(>2 \mathrm{~mm})$, and these effects were more intensive when in WSA, the content of soil organic carbon was higher. The threshold limits for $\mathrm{Mg}^{2+}$ for the formation of water-stable macro-aggregates were equal to $11.5 \mathrm{cmol} / \mathrm{kg}$, respectively. A further increase resulted in lower content of $\mathrm{WSA}_{\mathrm{ma}}$. To confirm the findings, more research is required in the future.

Acknowledgement. Partial support was provided by project CZ.1.05/1.1.00/02.0070 (IT4Innovations) and the PostDoc project "Opportunity for young researchers” No. CZ.1.07/2.3.00/30.0016.

\section{REFERENCES}

ALAGÖZ, Z. - YILMAZ, E. 2009. Effects of different sources of organic matter on soil aggregate formation and stability: A laboratory study on a Lithic Rhodoxeralf from Turkey. In Soil and Tillage Research, vol. 103, pp. 419-424. DOI:10.1016/j.still.2008.12.006.

AMÉZKETA, E. 1999. Soil aggregate stability: a review. In Journal of Sustainable Agriculture, vol. 14, pp. 83-151. DOI: 10.1300/J064v14n02_08.

BALASHOV, E. - BUCHKINA, N. 2011. Impact of shortand long-term agricultural use of chernozem on its quality indicators. In International Agrophysics, vol. 25, pp. 1-5. 
BIELEK, P. - ŠURINA, B. - ILAVSKÁ, B. - VILČEK, J. 1998. Naše pôdy [Our soils]. Bratislava : VÚPÚ, $82 \mathrm{p}$.

BLANCO-CANQUI, H. - LAL, R. 2007. Soil structure and organic carbon relationships following 10 years of wheat straw management in no-till. In Soil and Tillage Research, vol. 95, pp. 240-254. DOI: 10.1016/j. still.2007.01.004.

BOIX-FAYOS, C. - CALVO-CASES, A. - IMESON, A.C. 2001. Influence of soil properties on the aggregation of some Mediterranean soils and the use of aggregate size and stability as land degradation indicators. In Catena, vol. 44, pp. 47-67. DOI: 10.1016/S03418162(00)00176-4.

BRONICK, C.J. - LAL, R. 2005. The soil structure and land management: a review. In Geoderma, vol. 124, pp. 3-22. DOI:10.1016/j.geoderma.2004.03.005.

CERDA, A. 1996. Soil aggregate stability in three Mediterranean environments. In Soil Technology, vol. 9, pp. 133-140.

DEXTER, A.R. 1988. Advances in characterization of soil structure. In Soil and Tillage Research, vol. 11, pp. 199-238.

DIMOYIANNIS, D.G. - TSADILAS C.D. - VALMIS S. 1998. Factors affecting aggregate stability of Greek agricurtural soils. In Communications in Soil Science and plant analysis, vol. 29, pp. 1239-1251.

DUCHAUfOUR, P. 1982. Pedology (Pedogenesis and classification). London: George Allen and Unwin, 1982, $386 \mathrm{p}$.

DZIADOWIEC, H. - GONET, S.S. 1999. Przewodnik metodyczny do badań materii organicznej gleb [Methodical guide-book for soil organic matter studies]. Prace Komisji Naukowych Polskiego Towarzystwa Gleboznawczego, N. 120, Komisja chemii gleb, Zespół Materii Organicznej Gleb, N II/16, 65 p.

ECKMEIER, E. - GERLACH, R. - GEHRT, E. - SCHMIDT, M.W.I. 2007. Pedogenesis of chernozems in Central Europe - a review. In Geoderma, vol. 139, 2007, pp. 288-299. DOI: 10.1016/j.geoderma.2007.01.009.

FIALA, K. - KOBZA, J. - MATÚŠKOVÁ, L. - BREČKOVÁ, V. - MAKOVNÍKOVÁ, J. - BARANČÍKOVÁ, G. - BÚRIK, V. - LITAVEC, T. - HOUŠKOVÁ, B. - CHROMANIČOVÁ, A. - VÁRADIOVÁ, D. - PECHOVÁ B. 1999. Záväzné metódy rozborov pôd. Čiastkový monitorovací system - Pôda [Approved methods of soil analyses. Partial monitoring system - Soil]. Bratislava : VÚPOP, 142 p.

GONZÁlEZ, C. - QUINTANA, J.R. - MORENO, L. VÁZQUEZ, A. - LAFUENTE, A.L. - ROMERO, A. 2007. Applying multivariate methods to soil-solution interactions in carbonate media. In Geoder$m a$, vol. 137, pp. 352-359. DOI: 10.1016/j.geoderma.2006.08.016.

GREENE, R.S.B. - EGGLETON, R.A. - RENGASAMY, P. 2002. Relationships between clay mineralogy and the hardsetting properties of soils in the Carnarvon horticultural district of Western Australia. In Applied Clay Science, vol. 20, pp. 211-223.

GUGGENBERGER, G. - RODIONOV, A. - SHIBISTOVA, O. - GRABE, M. - KASANSKY, O.A. - FUCHS,
H. - MIKHEYEVA, N. - ZRAZHEVSKAYA, G. FLESSA, H. 2008. Storage and mobility of black carbon in permafrost soils of the forest tundra ecotone in Northern Siberia. In Global Change Biology, vol. 14, pp. 1367-1381.

HAYNES, R.J. - NAIDU, R. 1998. Influence of lime, fertilizer and manure applications on soil organic matter content and soil physical conditions: a review. In Nutrient Cycling in Agroecosystems, vol. 51, pp. 123-137. DOI: 10.1023/A:1009738307837.

HAYNES, R.J. 2005. Labile organic matter fractions as central components of the quality of agricultural soils: an overview. In Advances in Agronomy, vol. 85, pp. 221-268. DOI: 10.1016/S0065-2113(04)850053.

HUNGATE, A. - JACKSON, R.B. - FIELD, C.B. CHAPIN, F.S. 1996. Detecting changes in soil carbon in $\mathrm{CO}_{2}$ enrichment experiments. In Plant and Soil, vol. 187, pp. 135-145.

CHAN, K.Y.-HEENAN, D.P. 1999. Lime-induced loss of soil organic carbon and effect on aggregate stability. In Soil Science Society of America Journal, vol. 63, pp. 1841-1844.

IUSS Working Group WRB. 2006. World reference base for soil resources 2006. 2nd edition. World Soil Resources Reports No. 103. Rome: FAO, pp. 145.

JANZEN, H.H. - CAMPELL, C.A. - ELLERT, B.H. BREMER, E. 1997. Soil organic matter dynamics and their relationship to soil quality. In GREGORICH, E.G. - CARTER, M.R. (Eds.), Soil Quality for Crop Production and Ecosystem Health. Elservier, Amsterdam, pp. 277-291.

KROL, A. - LIPIEC, J. - TURSKI, M. - KUS, J. 2013. Effects of organic and conventional management on physical properties of soil aggregates. In International Agrophysics, vol. 27, pp. 15-21. DOI: $10.2478 / \mathrm{v} 10247-012-0063-1$.

LADO, M. - BEN-HUR, M. - SHAINBERG, I. 2004. Soil wetting and texture effects on aggregate stability, seal formation, and erosion. In Soil Science Society of America Journal, vol. 68, pp. 1992-1999.

LAL, R. - SHUKLA, M.K. 2004. Principles of soil physics. New York: Marcel Dekker, 716 p.

LE BISSONNAIS, Y. 1996. Aggregate stability and assessment of soil crustibility and erodibility: I. Theory and methodology. In European Journal of Soil Science, vol. 47, pp. 425-437.

ŁOGINOW, W. - WISNIEWSKI, W. - GONET, S.S. CIESCINSKA, B. 1987. Fractionation of organic carbon based on susceptibility to oxidation. In Polish Journal of Soil Science, vol. 20, pp. 47-52.

POZZUOLI, A. - VIAL, E. - FRANCO, E. - RUIZAMIL, A. - DE LA CALLE, C. 1992. Weathering of biotite to vermiculite in quaternary lahars form Monti Ernici, Central Italy. In Clay Minerals, vol. 27, pp. $175-184$.

Righi, D. - PETIT, S. - BOUCHET, A. 1993. Characterization of hydroxy-interlayered vermiculite and illite/smectite interstratified minerals from the weathering of chlorite in a cryorthod. In Clays and Clay Minerals, vol. 41, pp. 484-495. 
SIX, J. - BOSSUYT, H. - DEGRYZE, S. - DENEF, K. 2004. A history of research on the link between (micro)aggregates, soil biota, and soil organic matter dynamics. In Soil and Tillage Research, vol. 79, pp. 7-31. DOI: 10.1016/j.still.2004.03.008.

SLOWINSKA-JURKIEWICZ, A. - BRYK, M. - MEDVEDEV, V.V. 2013. Long-term organic fertilization on chernozem structure. In International Agrophysics. 27, 2013, pp. 81-87. DOI: 10.2478/v10247-0120071-1.

ŠIMANSKÝ, V. - BAJČAN, D. 2014. The stability of soil aggregates and their ability of carbon sequestration. In Soil and Water Research, vol. 9, pp. 111-118.

ŠIMANSKÝ, V. 2011. Chemical properties, soil structure and organic matter in different soil managements and their relationships with carbon sequestration in water-stable aggregates. In Research Journal of Agricultural Science, vol. 43, pp. 138-149.

ŠIMANSKÝ, V. 2012a. Assessment of soil structure under monoculture of vine. In Roczniki Gleboznawcze, vol. 63, pp. 42-45. DOI: 10.2478/v10239-012-00232.

ŠIMANSKÝ, V. 2012b. Soil structure stability and distribution of carbon in water-stable aggregates in different tilled and fertilized Haplic Luvisol. In Acta Universitatis Agriculturae et Silviculturae Mendeleianae Brunensis, vol. 60, pp. 173-178.

ŠIMANSKÝ, V. 2013. Soil organic matter in water-stable aggregates under different soil management practic- es in a productive vineyard. In Archives of Agronomy and Soil Science, vol. 59, pp. 1207-1214. DOI: 10.1080/03650340.2012.708103.

TISDALL, J.M. 1996. Formation of soil aggregates and accumulation of soil organic mater. In CATER, M.R. - STEWART, B.A. (Eds.) Structure and organic matter storage in agricultural soils. CRC Press, Boca Raton, F1, pp. 57-96.

TISDALL, J.M. - OADES, J.M. 1982. Organic matter and water-stable aggregates in soils. In Journal of Soil Science, vol. 33, pp. 141-163.

VADJUNINA, A.F. - KORCHAGINA, Z.A. 1986. Methods of study of soil physical properties. Moscow : Agropromizdat, $415 \mathrm{p}$.

VAEZI, A.R. - SADEGHI, S.H.R. - BAHRAMI, H.A. MAHDIAN, M.H. 2008. Modeling the USLE K-factor for calcareous soils in northwestern Iran. In Geomorphology, vol. 97, pp. 414-423. DOI: 10.1016/j.geomorph.2007.08.017.

ZAUJEC, A. - CHLPÍK, J. - NÁDAŠSKÝ, J. - SZOMBATHOVÁ, N. - TOBIAŠOVÁ, E. 2009. Pedológia a základy geológie [Pedology and principles of geo$\log y$ ]. Nitra: SUA, pp. 399.

ZHANG, X.C. - NORTON, L.D. 2002. Effect of exchangeable $\mathrm{Mg}$ on saturated hydraulic conductivity, disaggregation and clay dispersion of disturbed soils. In Journal of Hydrology, vol. 260, pp. 194-205. DOI: 10.1016/S0022-1694(01)00612-6.

Received: July 10, 2014 